\title{
ПЕДАГОГІЧНІ УМОВИ ФОРМУВАННЯ САМОВДОСКОНАЛЕННЯ МАЙБУТНІХ ЛІКАРІВ ЗАСОБАМИ ІНФОРМАЦЙНИХ ТЕХНОЛОГІЙ
}

\author{
Габорець О. А. \\ асистент кафедри медичної фізики та інформаційних технологій № 2 \\ Донеиький національний медичний університет \\ вул. Привокзальна, 27, Лиман, Донеиька область, Украӥна \\ orcid.org/0000-0001-7791-6795 \\ olga-gaborets@ukr.net
}

\begin{abstract}
Ключові слова: педагогічні умови; майбутні лікарі; інформачійні технології; формування самовдосконалення.
\end{abstract}

\begin{abstract}
Стаття присвячена проблемі формування самовдосконалення майбутніх лікарів в умовах ефективного впровадження сучасних освітніх інформаційних технологій у навчальному процесі вищого медичного навчального закладу освіти. Шляхом вивчення й аналізу науково-педагогічної літератури автором розкрито сутність поняття «умова» та охарактеризовано зміст поняття «педагогічні умови», що трактується як комплекс взаємозалежних заходів педагогічного процесу, які забезпечують певне оновлення змісту навчання, застосування нових методик і технологій, планомірне формування у здобувачів компонентів педагогічної компетентності, тобто підвищення якості розвитку самовдосконалення до майбутньої професійної діяльності. Аналізуючи наукові розвідки щодо проблеми педагогічних умов формування самовдосконалення, автором визначені й теоретично обгрунтовані основні педагогічні умови ефективного впровадження сучасних інформаційних технологій (IT) в освітньому процесі вищого медичного навчального закладу освіти як засобу формування самовдосконаленню студентів-медиків. А саме: формування позитивної мотивації до використання інформаційних технологій у навчанні, що може відбуватися у разі дотримання певних етапів (потреба, позитивне ставлення, інтерес у використанні IT тощо) та сприяє формуванню системи знань, умінь і навичок щодо здійснення самовдосконалення; поетапне використання інформаційних технологій у навчальному процесі як засобу самовдосконалення в майбутній професійній діяльності, що дасть змогу ефективно досягати поставлених цілей шляхом візуалізації процесу вирішення проблеми; організація самостійної пізнавальної діяльності студентів засобами інформаційних технологій, що містить в собі розроблення та впровадження позааудиторних заходів як домінуючого елементу самореалізації і саморозвитку.
\end{abstract}




\title{
PEDAGOGICAL CONDITIONS OF FORMATION OF FUTURE PHYSICIANS' SELF-IMPROVEMENT BY MEANS OF INFORMATION TECHNOLOGY
}

\author{
Haborets O. A. \\ Assistant Lecturer at the Department of Medical Physics and Information Technologies № 2 \\ Donetsk National Medical University \\ Privokzalna str., 27, Lyman, Donetsk region, Ukraine \\ orcid.org/0000-0001-7791-6795 \\ olga-gaborets@ukr.net
}

Key words: pedagogical conditions; future physicians'; information technology; formation of self-improvement.

\begin{abstract}
The article is devoted to the problem of formation of self-improvement of future physicians' in the conditions of effective introduction of modern educational information technologies in the educational process of higher medical educational institution. By studying and analyzing the scientific and pedagogical literature, the author revealed the essence of the concept of «condition» and characterized the meaning of the concept of «pedagogical conditions», which is interpreted as a set of interdependent measures of the pedagogical process. Components of pedagogical competence is to improve the quality of self-improvement to future professional activity. Analyzing scientific research on the problem of pedagogical conditions for the formation of self-improvement, the author identified and theoretically substantiated the basic pedagogical conditions for effective implementation of modern information technology (IT) in the educational process of higher medical education as a means of forming self-improvement of medical students. That is the formation of positive motivation to use information technology in education, which can occur at certain stages (need, positive attitude, interest in the use of IT, etc.) and contributes to the formation of a system of knowledge, skills and abilities for self-improvement; gradual use of information technology in the educational process as a means of self-improvement in future professional activities, that will effectively achieve the goals by visualizing the process if problem solving; organization of independent cognitive activity of students by means of information technologies, that includes the development and implementation of extracurricular activities as a dominant element of self-realization and self-development.
\end{abstract}

Постановка проблеми. Інтенсивність зростання інформаційного потоку, темпи науково-технічного прогресу та глибина суспільних запитів на конкурентоспроможного фахівця вимагають від закладів вищої освіти (ЗВО) підготовки спеціаліста, здатного володіти широким світоглядом, інтегрувати свій потенціал у діяльність, відповідати сучасному рівню розвитку науки та вимогам суспільства, здатного до саморозвитку та самовдосконалення, використовуючи інноваційні інформаційні технології упродовж всього життя.

Сучасна освітня парадигма, а саме нова стратегія іiі реформування, спрямовує на пошук інноваційних підходів щодо науково обгрунтованого та послідовного організаційно-педагогічного забезпечення iï розвитку. Одним із шляхів розв'язання $\epsilon$ послідовне запровадження ефективних педагогічних умов, які забезпечать формування готовності майбутніх лікарів до професійного самовдосконалення засобами інформаційних технологій.
Аналіз останніх досліджень і публікацій. Дослідженню проблеми педагогічних умов формування самовдосконалення спеціалістів присвятили свої роботи низка вітчизняних Учених, таких як О.В. Діденко, Л.В. Дудікова, В.В. Ільчук, О.М. Єрахторіна, В.М. Плющ, О.В. Солодовник, К.О. Соцький та інші.

Проте аналіз літературних розвідок показує недостатнє розв'язання проблеми формування самовдосконалення майбутніх лікарів засобами IT.

Метою статті $\epsilon$ науково-методичне обгрунтування педагогічних умов упровадження інформаційних технологій як засобу формування самовдосконалення майбутніх лікарів.

Виклад основного матеріалу дослідження. Формування готовності до самовдосконалення майбутніх лікарів засобами IT є досить складним процесом, результативність якого залежить від дотримання певних педагогічних умов. 
Для глибшого розуміння поняття «педагогічні умови» та методики ї реалізації проаналізуємо поняття «умова». 3 наукового погляду, «умова» має неоднозначне тлумачення і трактується як:

- «обставина, від якої щось залежить, або вимога до чогось» [1];

- «правила, що визначені в будь-якій галузі життєдіяльності» [1];

- «обстановка, в якій будь-що відбувається» [1];

- «необхідна обставина, яка уможливлює здійснення, створення, утворення чого-небудь або сприяє чомусь» [2];

- «домовленість про що-небудь» [3].

3 погляду філософії поняття «умова» трактується таким чином:

- «філософська категорія, що відображає відношення предмета до явищ, що його оточують, без яких він не може існувати» [4];

- «середовище, обставини, у яких оточуючі предмет явища виникають, існують і розвиваються» [4];

- «те, від чого залежить щось інше (що зумовлюється)» [5];

- «істотний компонент комплексу об'єктів (речей, їх станів, взаємодій), із наявності якого в разі необхідності відбувається здійснення цього явища» [5];

- «середовище, без якого неможливо існувати, знаходячись у ньому» [6];

- «ситуація, в якій щось відбувається» [6].

Проведений аналіз цієї дефініції показує, що дослідники по-різному іiі трактують. Проте більшість науковців під педагогічними умовами розглядають сукупність методів, організаційних форм та прийомів навчання, які оптимально відповідають змісту підготовки здобувачів та забезпечують виконання державних освітніх стандартів.

Поняття «педагогічні умови» стосується різних аспектів усіх складників процесу навчання, виховання і розвитку: цілей, змісту, принципів, методів, форм, засобів тощо. Воно може вживатися стосовно цілісного навчально-виховного процесу під час характеристики педагогічної системи або окремих її сторін чи елементів. Як правило, під педагогічними умовами розуміють такі, що спеціально створюються в освітньому процесі 3 метою підвищення його ефективності або реалізації певних інновацій.

Питання щодо педагогічних умов стали предметом уваги багатьох дослідників. Так, О.Ф. Федорова педагогічні умови визначає як сукупність об'єктивних можливостей змісту навчання, методів, організаційних форм та матеріальних можливостей iї здійснення, що забезпечують успішне вирішення поставленого завдання. Науковці А.М. Алексюк, А.А. Аюрзанайн, П.І. Підкасистий стверджують, що педагогічними умо- вами впливають на процес досягнення мети, при цьому їх поділяють на: а) зовнішні: позитивні відносини викладача і студента; об'єктивність оцінки навчального процесу; місце навчання, приміщення, клімат тощо; б) внутрішні (індивідуальні): індивідуальні властивості студентів (стан здоров'я, властивості характеру, досвід, уміння, навички, мотивація тощо) [7]. У свою чергу B.М. Манько педагогічні умови розрізняе як взаємопов'язану сукупність внутрішніх параметрів та зовнішніх характеристик функціонування, яка забезпечує високу результативність навчального процесу і відповідає психолого-педагогічним критеріям оптимальності [8]. С.І. Тихолаз [9] педагогічні умови трактує як структурну оболонку педагогічних технологій чи педагогічних моделей. Зокрема, А.Я. Найн зазначає, що педагогічні умови - це сукупність об'єктивних можливостей змісту, форм, методів, прийомів, засобів педагогічного управління та матеріально-просторового середовища, що забезпечують успішне вирішення поставлених та спроектованих завдань [10]. Є.А. Іванченко, досліджуючи процес формування професійної мобільності майбутніх економістів, визначає педагогічну умову як обставину, яка впливає на розвиток професійних та особистісних якостей студентів [11].

Педагогічні умови, на думку Д.А. Костюка, це сукупність вимог, за додержання яких забезпечується досягнення поставленої мети, тобто підвищення ефективності процесу фахової підготовки людей із вищою освітою [12]. Б.С. Гершунський трактує педагогічні умови як певну суму наукових знань, які педагог повинен засвоїти до моменту ухвалення педагогічних рішень [13].

Отже, аналізуючи різні погляди дослідників стосовно трактування феномену «педагогічні умови», можна визначити педагогічні умови як комплекс взаємозумовлених i взаємозалежних заходів педагогічного процесу, що забезпечують оновлення змісту навчання, застосування новітніх методик і технологій, цілеспрямоване формування у майбутніх фахівців компонентів педагогічної компетентності та, як результат, підвищення якості розвитку самовдосконалення до майбутньої професійної діяльності.

Спираючись на практичну доцільність на основі теоретичного узагальнення наведених аспектів, визначаємо, що формування у студентів-медиків самовдосконалення засобами IT залежить від реалізації комплексу таких педагогічних умов:

- формування позитивної мотивації до використання інформаційних технологій у навчанні;

- поетапне використання IT у навчальному процесі як засобу самовдосконалення в майбутній професійній діяльності; 
- організація самостійної пізнавальної діяльності студентів засобами інформаційних технологій.

Виділені нами педагогічні умови перебувають у тісному взаємозв'язку між собою та разом спрямовані на досягнення поставленої мети. Розглянемо детальніше кожну 3 педагогічних умов, націлених на використання інформаційних технологій майбутніми лікарями як засобу самовдосконалення.

Перша педагогічна умова - це формування позитивної мотивачії до використання інформаиійних технологій у навчанні.

Процес цілісного формування мотивації майбутніх лікарів до застосування інформаційних технологій у майбутній професійній діяльності повинен мати систематичний характер. До цієї системи входять теоретичні і практичні завдання із використанням IT.

Усвідомлення особистісного сенсу та значущості інформаційних технологій у професійній діяльності майбутніх лікарів забезпечується за допомогою реалізації стратегії покрокового ускладнення завдань - від алгоритмічних до завдань творчого характеру, що потребують знань про особливості використання IT, уміння творчо підходити до розв'язання проблеми, здатність до рефлексії, власного досвіду володіння навичками опрацювання медичної інформації. Формування мотивації лікарів до застосування інформаційних технологій у майбутній професії відбувається за такими етапами, як: формування потреби у використанні IT; формування позитивного ставлення до використання IT; формування інтересу до використання IT; успішна професійна діяльність iз застосуванням IT.

Формування у майбутніх лікарів потреби до використання IT у процесі навчання відбувається на початковому етапі мотивації. Мотивацією професійного самовдосконалення фахівця $є$ сукупність усіх спонукань та умов, що детермінують, спрямовують і регулюють процес професійного самовдосконалення. Професійне самовдосконалення базується на досить складній системі мотивів і зумовлене різними джерелами активності. Рушійною силою та провідним джерелом розвитку фахівця $є$ потреба в самозміні й самовдосконаленні, що зумовлена суперечностями між мотивами власної професійної діяльності та метою iii досягнення в оновлених умовах. Забезпечити спрямування мотиву на мету - значить викликати дійсну потребу в самовдосконаленні.

Продуктивність професійного самовдосконалення багато в чому залежить від сили й структури професійної мотивації. Якщо в цій структурі внутрішні мотиви знаходяться на домінуючих позиціях або один із них є головним мотивом, то це забезпечує вмотивованість студента постійно самовдосконалюватися. Якщо ж провідним мотивом є лише один із зовнішніх мотивів і в структурі мотивації на позиціях домінуючих відсутні внутрішні мотиви, можна стверджувати про відсутність мотивації професійно самовдосконалюватися. Формування мотивів і удосконалення структури мотивації професійної діяльності - це процес відносно складний та довготривалий, тому сформувати вмотивованість самовдосконалення неможливо швидко, якщо їі немає у відповідній структурі мотивів. Наявність мотивації є однією 3 важливих професійних якостей медичного працівника, яка сприяє самостійній побудові кар'єри й досягненню успіху в процесі відповідних змін.

Здатність до самовдосконалення, на відміну від мотивації, можна сформувати й розвинути значно швидше. Основа здатності до самовдосконалення включає уміння: бачити власні недоліки й обмеження; аналізувати причини їх виникнення у власній діяльності; критично оцінювати процес та результати своєї роботи, причому як невдачі, так i успіхи. Зауважимо, що саме наявність мотивації та здатності до самовдосконалення свідчить про те, що студент сам може прикласти максимальних зусиль для того, щоб повністю реалізувати свої потенційні можливості професійного вдосконалення і розвитку та досягти відповідних успіхів.

Друга педагогічна умова - поетапне використання IT у навчальному прочесі як засобу самовдосконалення в майбутній професійній діяльності.

Питання застосування засобів IT у навчальному процесі є досить дослідженим у сучасній педагогіці. Майже всі дослідники вважають, що систематичне застосування засобів IT під час вивчення окремих дисциплін допоможе студентам закріпити та розширити передбачені навчальною програмою знання, уміння та навички, розвинути навички спілкування та комунікативні здібності, що здатні забезпечити ситуацію успіху при виконанні виробничих дій та реалізації типових завдань професійної діяльності. Також наголошується на тому, що в студентів виникає необхідність міркувати, висловлювати своє ставлення до подій, явищ, активно діяти, розвивати уміння керувати своїм емоційним станом та спілкуватися. Усе це створює ситуацію успіху, яка, на нашу думку, в майбутньому сформує успішного лікаря 3 креативним мисленням.

Використання IT дозволяє ефективно досягати навчальних цілей шляхом візуалізації процесу вирішення проблеми, оперативного пошуку інформації на основі вільного доступу до інформаційних джерел, швидкої обробки великих обсягів інформації. Контроль, оцінювання та корекція у використанні IT дає можливість одночасного здійснення контролю та оцінки перебігу 
вирішення поставлених навчальних завдань 3 боку викладача та самоконтролю i самооцінки правильності виконання навчальних операцій самими студентами. Основними перевагами використання IT у викладанні навчальних дисциплін можна визначити практичну можливість індивідуалізації навчання, підвищення мотивації та активності студентів, інтенсифікацію самостійної роботи, зростання обсягу виконаних на навчальному занятті завдань, розширення інформаційних потоків, оперативний контроль і корекцію. Використання комп'ютеру можливе на всіх етапах організації педагогічного процесу та зберігає у студентів стан психологічного комфорту.

Основними перевагами використання IT у викладанні навчальних дисциплін можна визначити практичну можливість індивідуалізації навчання, підвищення мотивації та активності студентів, інтенсифікацію самостійної роботи, зростання обсягу виконаних на навчальному занятті завдань, розширення інформаційних потоків, оперативний контроль і корекцію. Використання комп'ютера можливе на всіх етапах організації педагогічного процесу та зберігає у студентів стан психологічного комфорту.

Отже, використання засобів IT у певних межах $\epsilon$ сучасним підходом до організації аудиторної, самостійної, дистанційної та дослідницької роботи студентів, що сприяє вдосконаленню наукового й методичного рівня надання освітніх послуг, дає змогу здійснювати індивідуальний підхід у навчанні, розвивати мотиваційну сферу, прагнення до систематичного самовдосконалення. Вважаємо, що використання IT оптимізуватиме процес розвитку та формування самовдосконаленні майбутніх лікарів, сприяючи усвідомленому засвоєнню знань у процесі виконання дослідницьких задач, даючи можливість опанувати прийоми самостійного пошуку, збору, обробки, аналізу та синтезу нової інформації, розвинути вміння та навички інформаційного саморозвитку з навчальної і науково-дослідної діяльності. Водночас актуальною проблемою самовдосконалення засобами IT майбутніх лікарів $є$ створення цілісності освітнього процесу та розвиток системності їх мислення.

Третя педагогічна умова - це організація самостійної пізнавальної діяльності студентів засобами інформаційних технологій.

Формуванню готовності майбутніх лікарів до самовдосконалення засобами IT сприяє розроблення та впровадження у медичному виші спеціально розробленої програми позааудиторних заходів. Зокрема, в Донецькому національному медичному університеті було впроваджено науковий гурток, на базі якого систематично організовуються круглі столи за темами: «Використання сучасних технологій у діагностиці та лікуванні соціально значущих захворювань» $\mathrm{i}$ «Медична реабілітація різних захворювань із застосуванням IT».

Також у навчальний процес нами було впроваджено факультатив «Європейський стандарт цифрової грамотності», який викладається 3 метою підвищення рівня базових знань студентів у галузі інформаційних технологій, удосконалення навичок особистого користування комп'ютером та найпоширенішого комп'ютерного програмного забезпечення для розвитку інформаційної компетентності у майбутніх лікарів.

Предметом вивчення дисципліни є інформаційні процеси, що забезпечують використання персонального комп'ютера.

Метою курсу «Європейський стандарт цифрової грамотності» є: формування та розвиток основних компетенцій інформаційних технологій для забезпечення раціонального використання сучасного програмного забезпечення загального призначення в обробці даних.

Основними завданнями вивчення дисципліни є:

- формування та розвиток знань, умінь та баз знань, необхідних для ефективного використання сучасних додатків загального призначення в навчально-пізнавальній діяльності та повсякденному житті;

- ознайомлення студентів 3 роллю нових інформаційних технологій у професійній діяльності, 3 перспективами розвитку комп'ютерного обладнання;

- вироблення вміння самостійно опановувати різні програмні засоби та оновлювати та інтегрувати набуті знання.

Відповідно до вимог стандартної дисципліни «Свропейський стандарт цифрової грамотності» надає студентам компетенціі:

- здатність вирішувати типові та складні спеціалізовані та практичні завдання, пов'язані iз питаннями професійної медичної допомоги, використовуючи персональний комп'ютер та працюючи із загальним призначенням додатків, та включає дослідження та / або інновації та характеризується складністю та невизначеністю вимог;

- вміння застосовувати знання в практичних ситуаціях;

- вміння вибирати комунікаційну стратегію;

- вміння працювати в колективі; навички міжособистісного спілкування;

- використовувати навички інформаційних та комунікаційних технологій;

- здатність до абстрактного мислення, аналізу та синтезу, здатність до вивчення та сучасного навчання;

- вміння застосовувати знання в практичних ситуаціях;

- вміння оцінювати та забезпечувати якість виконаної роботи; 
- рішучість та наполегливість щодо поставлених завдань та завдань;

- здатність обробляти державну, соціальну, економічну та медичну інформацію;

- визначити джерело та / або місце знаходження потрібної інформації залежно від іiі типу;

- отримувати необхідну інформацію 3 конкретного джерела;

- розробити та проаналізувати отриману інформацію;

- демонструвати базові персональні навички роботи 3 комп'ютером та знайти біомедичні дані за допомогою інформаційних технологій.

Висновки та перспективи подальших досліджень. Успішна підготовка майбутніх лікарів у наш час не може обмежуватись лише засвоєнням ними фахових знань, умінь та навичок. Сучасне інформатизоване суспільство ставить перед лікарями нові умови, які включають уміння орієнту- ватись в інформаційному просторі і застосовувати IT у професійній діяльності.

Таким чином, сутність представленої проблеми полягає в радикальному оновленні духовної атмосфери, основ педагогічного процесу у ЗВО, урахуванні освітніх запитів студентів, потреб суспільства, тенденцій його розвитку. Дотримання виділених педагогічних умов, на нашу думку, сприяє усвідомленню викладачем своєї професійної сутності, ефективному самовдосконаленню, самореалізації та самоактуалізації, коли педагог вищої школи перетворюється на творця своїх життєвих і професійних обставин, самовизначається в професійній діяльності.

Перспектива подальшого дослідження полягає у визначенні моделі формування готовності майбутніх лікарів до професійного самовдосконалення засобами інформаційних технологій у процесі фахової підготовки.

\section{ЛІТЕРАТУРА}

1. Гончаренко С.У. Український педагогічний енциклопедичний словник. 2-е вид., доn. i випр. Рівне : Волинські обереги, 2011. 519 с.

2. Булыгин Ю.Е. Организация социального управления (основные понятия и категории) : словарь-справочник. М. : Контур, 1999. 256 с.

3. Бусел В. Т. “Великий тлумачний словник сучасної української мови (з дод. і допов.)" / Уклад. і голов. ред. В. Т. Бусел. К., Ірпінь : ВТФ «Перун», 2005. 1728 с.

4. Всемирная энциклопедия: Философия / [глав. науч. ред. и сост. А.А. Грицанов]. М. : АСТ; Мн. : Харвест, Современный литератор, 2001. 1312 с.

5. Философский энциклопедический словарь / гл. ред. : Л.Ф. Ильичев, П.Н. Федосеев, С.М. Ковалев, В.Г. Панов. М. : Советская энциклопедия, 1983. - 840 с.

6. Философский энциклопедический словарь / Е.Ф. Губский, Г.В. Кораблева, В. А. Лутченко. М. : ИНФРА-М, 2007. 575 c.

7. Антипова В.М. Компетентностный подход к организации дополнительного педагогического образования в университете. Педагогика. 2006. № 8. С. 34-37.

8. Манько В.М. Дидактичні умови формування у студентів професійно-пізнавального інтересу до спеціальних дисциплін. Соціалізація особистості : зб. наук. пр. Національного педагогічного ун-ту ім. М. Драгоманова. К. : Логос, 2000. Вип. 2. С. 153-161.

9. Тихолаз С.I. "Педагогічні умови розвитку професійної спрямованості студентів вищих медичних навчальних закладів : автореферат дисертації на здобуття наукового ступеня канд. пед. наук : 13.00.04 «Теорія і методика професійної освіти». Вінницький державний педагогічний ун-т. Вінниця, 2011. 20 с.

10. Найн А.Я., Клюев Ф.Н. Проблемы развития профессионального образования: региональный аспект. Челябинск : Изд-во Челябинского инта развития профессионал. образования, 1998. 264 с.

11. Іванченко Є.А. Формування професійної мобільності майбутніх економістів у процесі навчання у вищих навчальних закладах : дис. ... кандидата пед. наук : 13.00.04. Одеса, 2005. 235 с.

12. Костюк Д.А. Педагогічні умови формування фахової компетентності у майбутніх техніків-електриків сільського господарства. Науковий вісник Національного університету біоресурсів і природокористування України. Серія : Педагогіка, психологія, філософія. 2014. Вип. 199(2). С. 344-349.

13. Гершунский Б.С. Методические проблемы использования компьютерной техники в системе образования и педагогической науке. Программированное обучение. Вып. 23. М., 1996.

\section{REFERENCES}

1. Honcharenko S.U. (2011). Ukrayinskij pedagogichnij encziklopedichnij slovnik [Ukrainian pedagogical encyclopedic vocabulary], Rivne: Volynski oberehy (in Ukrainian). 
2. Bulyhyn, Yu.E. (1999). Organizacziya soczialnogo upravleniya (osnovnye ponyatiya $i$ kategorii) [Organization of social management (basic concepts and categories)], Moscow: Kontur. (in Russian)

3. Busel V. T. (2005). Velikij tlumachnij slovnik suchasnoyi ukrayinskoyi movi [Large explanatory dictionary of the modern Ukrainian language], Irpin: VTF «Perun». (in Ukrainian)

4. Hrytsanov A.A. (2001). Vsemirnaya encziklopediya: Filosofiya [World Encyclopedia: Philosophy], Moscow: AST. (in Russian)

5. Ylychev L.F., Fedoseev P.N., Kovalev S.M., Panov V.H. (1983). Filosofskij encziklopedicheskij slovar [Philosophical Encyclopedic Dictionary], Moscow: Sovetskaia entsyklopedyia. (in Russian)

6. Hubskyi E.F., Korableva H.V., Lutchenko V.A. (2007). Filosofskij encziklopedicheskij slovar [Philosophical Encyclopedic Dictionary], Moscow: YNFRA-M. (in Russian)

7. Antypova V.M. (2006). Kompetentnostnyj podkhod $k$ organizaczii dopolnitelnogo pedagogicheskogo obrazovaniya v universitete [Competence approach to the organization of additional pedagogical education at the university], Pedahohyka, vol. 8., pp. 34-37.

8. Manko V.M. (2000). Didaktichni umovi formuvannya u studentiv profesijno-piznavalnogo interesu do speczialnikh discziplin [Didactic conditions for the formation of students professional and cognitive interest in special disciplines], Sotsializatsiia osobystosti : zb. nauk. pr. Natsionalnoho pedahohichnoho un-tu im. M. Drahomanova. Kyiv: Lohos, vol. 2., pp. 153-161.

9. Tykholaz S.I. (2011). Pedagogichni umovi rozvitku profesijnoyi spryamovanosti studentiv vishhikh medichnikh navchalnikh zakladiv [Pedagogical conditions for the development of professional orientation of students of higher medical educational institutions] (PhD Thesis), Vinnytsia: Vinnytsia State Pedagogical University.

10. Nain A. Ya., Kliuev F. N. (1998). Problemy razvitiya professionalnogo obrazovaniya: regionalnyj aspekt [Problems of Vocational Education Development: Regional Aspect], Cheliabynsk: Yzd-vo Cheliabynskoho ynta razvytyia professyonal. obrazovanyia. (in Russian)

11. Ivanchenko Ye.A. (2005). Formuvannya profesijnoyi mobilnosti majbutnikh ekonomistiv u proczesi navchannya u vishhikh navchalnikh zakladakh [Formation of professional mobility of future economists in the process of studying in higher educational institutions] (PhD Thesis), Odesa.

12. Kostiuk D.A. (2014). Pedagogichni umovi formuvannya fakhovoyi kompetentnosti u majbutnikh tekhnikiv-elektrikiv silskogo gospodarstva [Pedagogical conditions for the formation of professional competence in future agricultural electricians], Naukovyi visnyk Natsionalnoho universytetu bioresursiv i pryrodokorystuvannia Ukrainy. Seriia : Pedahohika, psykholohiia, filosofiia, vol. 199(2), pp. 344-349.

13. Hershunskyi B.S. (1996). Metodicheskie problemy ispolzovaniya kompyuternoj tekhniki v sisteme obrazovaniya i pedagogicheskoj nauke [Methodological problems of using computer technology in the education system and pedagogical science], Prohrammyrovannoe obuchenye, vol. 23. 